\title{
Effects of Dietary Proteins on Plasma Lipoprotein Levels in Normal Subjects: Interaction with Dietary Cholesterol
}

\author{
Hans MEINERTZ, ${ }^{1}$ Karin NILAUSEN, ${ }^{2}$ and Ole FAERGEMAN ${ }^{1}$ \\ ${ }^{1}$ Department of Medicine B, Rigshospital, Blegdamsvej 9, 2100 Copenhagen, Denmark \\ ${ }^{2}$ Department of Anatomy C, Panum Institute, University of Copenhagen, \\ Blegdamsvej 3, 2200 Copenhagen, Denmark
}

Summary We have compared the effects of dietary soy protein and casein in diets low in cholesterol (less than $100 \mathrm{mg} / \mathrm{d}$ ) and in diets enriched in cholesterol $(500 \mathrm{mg} / \mathrm{d})$ to examine whether the level of cholesterol intake affects the response of plasma lipoproteins to dietary proteins of plant and animal origin. Normal men and women consumed formula diets containing $20 \%$ of calories as soy protein or casein, $27 \%$ as fat and $53 \%$ as carbohydrate in 2 crossover studies. The dietary periods lasted for 31 days and were separated by a month-long interim period on self-chosen food. Following an initial reduction of plasma total cholesterol and low-density lipoprotein-cholesterol (LDL-C) levels on all diets, the plasma lipid and lipoprotein concentrations stabilized. On lowcholesterol diets the concentration of each of the major lipoprotein classes were similar during the soy and the casein dietary periods. On cholesterolenriched diets, the concentration of LDL-C stabilized at a $16 \%$ lower level on soy protein than on the casein diet $(p<0.02)$, while the concentration of high-density lipoprotein-cholesterol (HDL-C) was $16 \%$ higher $(p<0.01)$. Since the difference in LDL-C $(p<0.05)$ and in HDL-C $(p<0.025)$ levels on casein and on soy protein diets were significantly greater on the high than on the low cholesterol intake, the findings indicate that the level of dietary cholesterol may determine whether plant and animal dietary proteins have similar or different effects on plasma LDL-C and HDL-C concentrations.

Key Words soy protein, casein, dietary cholesterol, liquid-formula diets, plasma lipids, plasma lipoproteins, normolipidemic subjects

\section{Introduction}

Studies of the effects of dietary proteins on plasma lipids and lipoproteins in humans have yielded variable and apparently contradictory findings. Both hyperlipidemic patients and normolipidemic subjects have in some investigations shown identical effects of animal and plant proteins (1-4), whereas other studies have demonstrated beneficial effects of vegetable proteins by inducing either lower levels of plasma total cholesterol, triglycerides, LDL-C, and very low density lipoprotein-cholesterol (VLDL-C), or higher levels of HDL-C, compared to those obtained with animal proteins $(1,2,5-8)$. The cause of these discrepancies is not known, but one possibility is that the proteins interact with other dietary components. Thus, it has been shown that the type of dietary fiber ( 9 ), addition of certain amino acids to diets (10), and the degree of saturation of dietary fats (11) affected both plasma lipid levels and extent of arterial lesions in rabbits fed casein and soy protein. In human studies also, dietary saturated and unsaturated fats affect the response of hypercholesterolemic patients to dietary soy protein (6). Cholesterol is another dietary component which in a number of animals, such as rat, mouse, pig and chicken generally must be present in order that dietary casein and soy protein display different effects on plasma cholesterol levels (12). In a study of hypercholesterolemic patients, however, no effect was observed on cholesterol-lowering by dietary soy protein, whether the intake of cholesterol was low or high (6).

We wanted to examine whether dietary cholesterol plays a role in the effects of animal and vegetable proteins on circulating lipoproteins. For this purpose we conduced 2 studies on normolipidemic subjects using diets with a low (13) and with a high (14) cholesterol content, but otherwise identically composed. The present report is based on 
Table 1. Comparison of participants receiving lowcholesterol and cholesterol-enriched diets.

\begin{tabular}{|c|c|c|}
\hline & $\begin{array}{c}\text { Low-cholesterol } \\
\text { diets }\end{array}$ & $\begin{array}{l}\text { Cholesterol- } \\
\text { enriched diets }\end{array}$ \\
\hline Women, $n$ & 5 & 6 \\
\hline Men, $n$ & 5 & 5 \\
\hline Age, years & $41 \pm 14^{*}$ & $38 \pm 10$ \\
\hline Body weight, $\mathrm{kg}$ & $62 \pm 10$ & $64 \pm 12$ \\
\hline \multicolumn{3}{|l|}{ Body weight, } \\
\hline \multirow[t]{2}{*}{$\%$ of ideal** } & $93 \pm 6$ & $96 \pm 10$ \\
\hline & \multicolumn{2}{|c|}{$\mathrm{mg} / 100 \mathrm{ml}$} \\
\hline Plasma cholesterol & $171 \pm 32$ & $170 \pm 41$ \\
\hline Plasma triglyceride & $68 \pm 32$ & $56 \pm 20$ \\
\hline Plasma VLDL-C & $13 \pm 7$ & $8 \pm 8$ \\
\hline Plasma LDL-C & $110 \pm 25$ & $105 \pm 37$ \\
\hline Plasma HDL-C & $47 \pm 13$ & $57 \pm 11$ \\
\hline
\end{tabular}

* Mean \pm SD of 10 and 11 subjects on low-cholesterol and cholesterol-enriched diets, respectively. There were no significant $(p>0.05)$ differences between the 2 groups. ** Calculated from the initial body weight percent of the midpoint for ideal body weight for height and medium frame according to the Metropolitan Life Insurance Tables, 1983.

both of those investigations.

\section{Methods}

Subjects The participants were all healthy, active women and men of normal body weight, who were normolipidemic (Table 1). They also had normal liver and kidney function and normal plasma levels of glucose, uric acid, albumin and electrolytes. The 2 groups of subjects participating in the lowcholesterol and in the cholesterol-enriched dietary studies, respectively, did not differ significantly in any of the characteristics listed in the table. Six subjects participated in both studies. The protocol, which was in accord with the Helsinki Declaration, was explained to each individual and informed consent was obtained.

Diets The low-cholesterol and the cholesterolenriched diets were identically composed, except that cholesterol (USP, Sigma) was added to the latter. The major ingredients are listed in Table 2. They also contained various salts, and calcium was added to the soy protein diets to compensate for the calcium contained in the casein preparation (Casec, Mead Johnson Laboratories). Both the casein and the soy protein isolate (Purina 660, The Ralston Purina
Table 2. Major ingredients of diets.

\begin{tabular}{lcc}
\hline & $\begin{array}{c}\text { Casein } \\
\text { diets } \\
(\mathrm{g})\end{array}$ & $\begin{array}{c}\text { Soy protein } \\
\text { diets } \\
(\mathrm{g})\end{array}$ \\
\hline $\begin{array}{c}\text { Protein }(20 \%)^{*} \\
\text { Calcium caseinate } \\
\text { Soy protein isolate }\end{array}$ & 139 & - \\
$\begin{array}{l}\text { Fat }(27 \%) \\
\text { Safflower oil } \\
\quad \text { (high oleinate) }\end{array}$ & 54 & 140 \\
$\begin{array}{c}\text { Carbohydrate }(53 \%) \\
\text { Corn starch hydrolysate }\end{array}$ & 260 & 54 \\
Water & 1100 & 1100 \\
\hline
\end{tabular}

* Percent of energy content.

Company) were $92 \%$ pure on a dry weight basis according to the manufacturers. Further details on dietary ingredients and composition have been published $(13,14)$. The participants received, in addition, a daily supplement of vitamins and trace minerals to satisfy minimal daily requirements. They were allowed calorie-free beverages and were specifically asked not to drink alcohol.

The diets were analyzed as previously described (13) for protein content and total fat, while the carbohydrate content was obtained by difference. The fatty acid composition as well as the sterol content and composition of the diets were analyzed by gas-liquid chromatography. The calcium content was determined by flame atomic absorption photometry.

Experimental design All subjects received both the soy protein and the casein diets, with or without cholesterol enrichment, in a crossover design for 31 days each, interrupted by a 30 day period on a diet of self-chosen food. Half of the participants started on the soy diet and the other half on the casein diet (Fig. 1).

Analysis of plasma lipids and lipoproteins For lipoprotein fractionation, freshly prepared EDTAplasma was centrifuged separately at densities 1.006 , 1.063 , and $1.125 \mathrm{~g} / \mathrm{ml}$ for $24 \mathrm{~h}$ at $180,000 \times g$. After centrifugation, the tubes were sliced, and top and bottom fractions were isolated quantitatively. Plasma concentration of VLDL-C was determined from the cholesterol content of the $d<1.006 \mathrm{~g} / \mathrm{ml}$ fraction. LDL-C plasma concentration was de- 
termined in the following ways: 1) as the difference in cholesterol content of the $d>1.006$ and the $d>1.063 \mathrm{~g} / \mathrm{ml}$ fractions, 2) from the cholesterol content of the $d>1.006 \mathrm{~g} / \mathrm{ml}$ fraction, before and after heparin- $\mathrm{MnCl}_{2}$ precipitation(15) of LDL, 3) as the difference in cholesterol content of the $d<1.063$ and the $d<1.006 \mathrm{~g} / \mathrm{ml}$ fractions, and 4) according to the formula of Friedewald et al. (16) from plasma total cholesterol, triglyceride and HDL-C (method 2; see below). Plasma concentration of HDL-C was determined in the following ways: 1) as the cholesterol content of the $d>1.063 \mathrm{~g} / \mathrm{ml}, 2$ ) as the cholesterol content of plasma after precipitation of LDL and VLDL by heparin- $\mathrm{MnCl}_{2}(15)$, and 3) as the cholesterol content of the $d>1.006 \mathrm{~g} / \mathrm{ml}$ after precipitation of LDL. $\mathrm{HDL}_{3}$-C was estimated as the cholesterol content of the $d>1.125 \mathrm{~g} / \mathrm{ml}$ fraction, and the

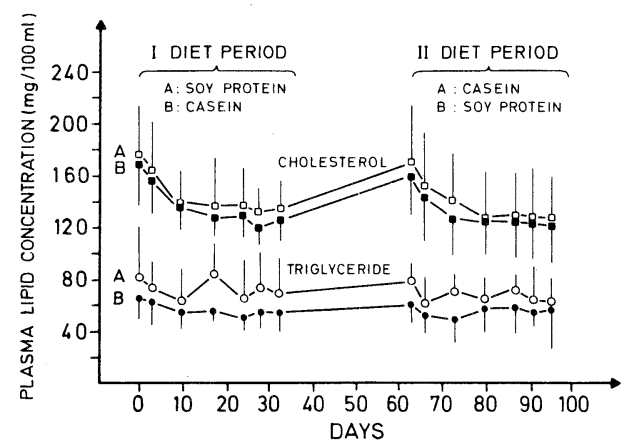

Fig. 1. Time course of plasma lipid concentrations during the two dietary periods on low-cholesterol diets, separated by a 30 day interval on a self-chosen diet. Each point and vertical bar represent mean and SD of 5 subjects. plasma concentration of $\mathrm{HDL}_{2}-\mathrm{C}$ as the difference between the cholesterol content of the $d>1.063 \mathrm{~g} / \mathrm{ml}$ fraction and $\mathrm{HDL}_{3}-\mathrm{C}$. Recoveries of cholesterol in the ultracentrifugal lipoprotein fractions and comparisons of the different procedures for determination of LDL-C and HDL-C concentrations have been described (14). Cholesterol(17) and triglycerides (18) were assayed by established procedures.

Statistical analysis Statistical evaluations were done by paired or unpaired Student's $t$-test.

\section{Results}

Intake of energy and nutrients Table 3 shows the mean daily intake of calories and nutrients calculated from the chemical composition of the diets and the amount of liquid formula consumed by each individual during the particular dietary period. The caloric intake on soy protein and casein diets were similar, and so were the modest decreases in body weight, namely $1.4 \pm 0.98 \mathrm{~kg}$ (mean \pm SD) (soy protein) and $1.2 \pm 1.03 \mathrm{~kg}$ (casein) on the low-cholesterol diets, and $1.1 \pm 0.78 \mathrm{~kg}$ (soy protein) and $1.1 \pm 0.81 \mathrm{~kg}$ (casein) on the cholesterol-enriched diets.

The fatty acid composition of the different diets were closely similar, oleic acid constituting about $72 \%$, linoleic acid about $17 \%$ and the saturated palmitic and stearic acids together about $11 \%$. Also the plant sterol composition of the different diets were virtually identical with beta-sitosterol, the main component, constituting about $64 \%$. The cholesterol intake was always less than $100 \mathrm{mg} / \mathrm{d}$ on the low-cholesterol diets, while it was about $500 \mathrm{mg} / \mathrm{d}$ on the average on the cholesterol-enriched diets. The

Table 3. Daily intake of energy and nutrients.

\begin{tabular}{|c|c|c|c|c|}
\hline & \multicolumn{2}{|c|}{ Low-cholesterol diets } & \multicolumn{2}{|c|}{ Cholesterol-enriched diets } \\
\hline & Casein & Soy protein & Casein & Soy protein \\
\hline Energy (kcal/d) & $2327 \pm 497^{*}$ & $2199 \pm 463$ & $2294 \pm 475$ & $2477 \pm 560$ \\
\hline Protein $(g / d)$ & $122 \pm 25$ & $111 \pm 23$ & $121 \pm 25$ & $112 \pm 25$ \\
\hline Fat $(g / d)$ & $67 \pm 14$ & $70 \pm 15$ & $69 \pm 14$ & $75 \pm 17$ \\
\hline Carbohydrate $(\mathrm{g} / \mathrm{d})$ & $307 \pm 66$ & $283 \pm 60$ & $296 \pm 61$ & $338 \pm 77$ \\
\hline Cholesterol (mg/d) & $72 \pm 15$ & $12 \pm 3$ & $549 \pm 114$ & $486 \pm 110$ \\
\hline Plant sterols $(\mathrm{mg} / \mathrm{d})$ & $214 \pm 46$ & $251 \pm 53$ & $224 \pm 46$ & $265 \pm 60$ \\
\hline Calcium $(\mathrm{mg} / \mathrm{d})$ & $620 \pm 133$ & $631 \pm 133$ & $579 \pm 120$ & $637 \pm 144$ \\
\hline
\end{tabular}

* Mean \pm SD of average daily intakes of 10 and 11 subjects on low-cholesterol and cholesterol-enriched diets, respectively. 


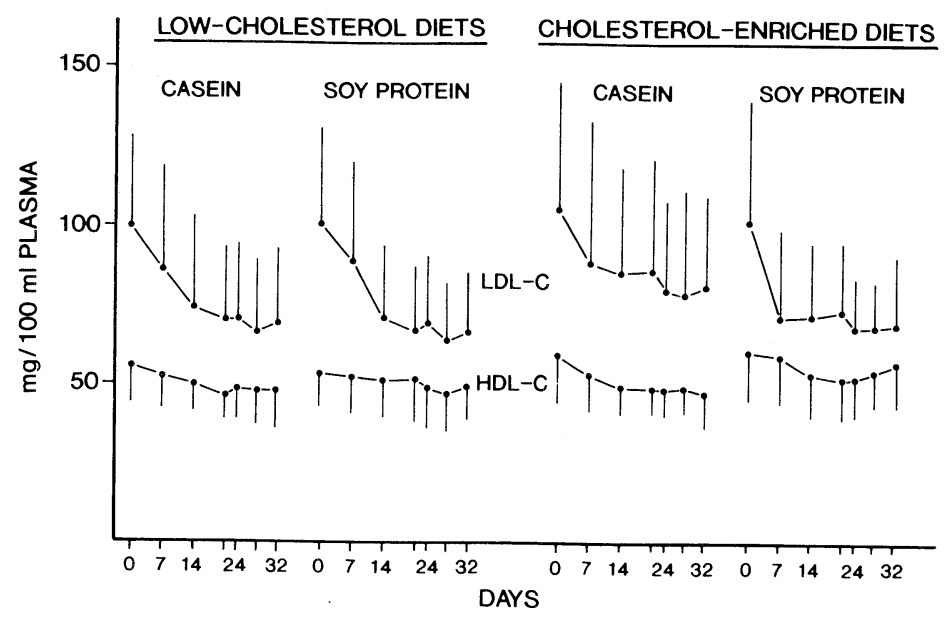

Fig. 2. Time course of low-density and high-density lipoprotein-cholesterol concentrations. Each point and bar represent mean and SD; $n=10$ for the low-cholesterol diets, and $n=11$ for the cholesterol-enriched diets.

mean daily cholesterol intake on the casein diets was always about $60 \mathrm{mg}$ higher than on the corresponding soy protein diet due to the presence of small amounts of cholesterol in the casein preparation.

Plasma concentrations of lipids and lipoprotein All experimental diets caused an initial fall in plasma total cholesterol of more than $20 \%$, whereas triglyceride levels were unaffected (Fig. 1). The reduction in plasma cholesterol was due primarily to a lowering of LDL-C levels, but also HDL-C concentrations decreased (Fig. 2). After about 2 weeks on the formula diets, plasma cholesterol and lipoprotein levels stabilized, and blood samples obtained after 24,28 , and 32 days of each dietary period was used to compare the effects of the 2 dietary proteins. During the month-long interval between the 2 dietary periods, when the participants consumed self-chosen food, plasma lipid and lipoprotein levels returned to prestudy values (Fig. $1)$.

During the last part of the experimental dietary periods, when plasma lipid and lipoprotein concentrations had become stable, plasma total cholesterol, triglyceride and VLDL-C levels were similar on the casein and the soy protein diets, regardless of the magnitude of cholesterol intake (Table 4). Correction for the predicted increase in plasma cholesterol on either low-cholesterol or cholesterol-enriched diets, due to the higher daily intake while on casein than on the soy protein diets (19), does not affect this result. In contrast, the response of LDL-C and HDL-C plasma levels to the 2 dietary proteins depended on the cholesterol content of the diets. On low-cholesterol diets, the mean plasma levels of LDL-C and HDL-C, determined by several different methods, were virtually identical whether the dietary protein was casein or soy protein. On cholesterol-enriched diets, however, LDL-C levels were significantly lower $(15-16 \%)$ on the soy protein than on the casein diet, while HDL-C concentrations were significantly higher $(12-16 \%)$ (Table 4). The difference in LDL-C levels on soy protein and casein diets was $1 \pm 10 \mathrm{mg} / 100 \mathrm{ml}$ plasma (Mean \pm SD) on lowcholesterol diets and $13 \pm 16 \mathrm{mg} / 100 \mathrm{ml}$ on cholesterol-enriched diets, and these differences were significantly $(p<0.05)$ different by unpaired comparison. For HDL-C the corresponding differences were $2 \pm 4$ and $8 \pm 6 / \mathrm{mg} / 100 \mathrm{ml}$, respectively, and they likewise were significantly different $(p<0.025)$.

Subfractionation of HDL revealed that the difference in HDL-C concentrations observed on cholesterol-enriched soy protein and casein diets was due mainly to differences in $\mathrm{HDL}_{2}-\mathrm{C}$ levels, which were $19 \%$ higher on the soy protein diet, whereas $\mathrm{HDL}_{3}-\mathrm{C}$ concentrations were similar. On lowcholesterol diets plasma levels of HDL subfractions were unaffected by the kind of dietary protein (Table 4). 
Table 4. Plasma lipid and lipoprotein-cholesterol concentrations on days 24,28 , and 32 of the dietary periods.

\begin{tabular}{|c|c|c|c|c|c|c|}
\hline \multirow[b]{4}{*}{ Cholesterol } & \multicolumn{3}{|c|}{ Low-cholesterol diets } & \multicolumn{3}{|c|}{ Cholesterol-enriched diets } \\
\hline & \multirow{2}{*}{\multicolumn{2}{|c|}{$\begin{array}{c}\text { Casein } \\
(\mathrm{mg} / 100 \mathrm{ml})\end{array}$}} & \multirow[b]{3}{*}{$\mathrm{NS} * 2$} & \multirow{2}{*}{\multicolumn{2}{|c|}{$\begin{array}{c}\text { Casein } \\
(\mathrm{mg} / 100 \mathrm{ml})\end{array}$}} & \multirow{3}{*}{$\begin{array}{c}p \\
\mathrm{NS}\end{array}$} \\
\hline & & & & & & \\
\hline & $125 \pm 24 * 1$ & $127 \pm 24$ & & $138 \pm 29$ & $133 \pm 19$ & \\
\hline Triglyceride & $56 \pm 14$ & $63 \pm 25$ & NS & $47 \pm 16$ & $51 \pm 18$ & NS \\
\hline VLDL-C & $7 \pm 2$ & $9 \pm 3$ & NS & $6 \pm 2$ & $7 \pm 2$ & NS \\
\hline \multicolumn{7}{|l|}{ LDL-C ${ }^{* 3}$} \\
\hline 1) & $67 \pm 19$ & $68 \pm 21$ & NS & $83 \pm 28$ & $70 \pm 14$ & $<0.02$ \\
\hline 2) & $66 \pm 18$ & $64 \pm 21$ & NS & $84 \pm 27$ & $73 \pm 16$ & $<0.025$ \\
\hline 3) & $68 \pm 19$ & $63 \pm 18$ & NS & $74 \pm 26$ & $63 \pm 14$ & $=0.07$ \\
\hline 4) & $68 \pm 23$ & $66 \pm 18$ & NS & $81 \pm 29$ & $68 \pm 17$ & $<0.025$ \\
\hline \multicolumn{7}{|l|}{ HDL-C ${ }^{* 4}$} \\
\hline 1) & $46 \pm 10$ & $48 \pm 9$ & NS & $47 \pm 9$ & $56 \pm 12$ & $<0.01$ \\
\hline 2) & $46 \pm 10$ & $47 \pm 11$ & NS & $48 \pm 10$ & $54 \pm 13$ & $<0.02$ \\
\hline 3) & $42 \pm 9$ & $43 \pm 10$ & NS & $47 \pm 10$ & $53 \pm 11$ & $<0.02$ \\
\hline $\mathrm{HDL}_{2}-\mathrm{C}^{* 5}$ & $21 \pm 12$ & $21 \pm 9$ & NS & $32 \pm 11$ & $38 \pm 12$ & $<0.01$ \\
\hline $\mathrm{HDL}_{3}-\mathrm{C}^{* 6}$ & $26 \pm 4$ & $26 \pm 3$ & NS & $16 \pm 7$ & $18 \pm 6$ & NS \\
\hline
\end{tabular}

${ }^{* 1}$ Mean \pm SD of 10 and 11 subjects on low-cholesterol and cholesterol-enriched diets, respectively; the value for each subject was calculated as the mean of concentrations on day 24,28 , and 32 of each dietary period. ${ }^{* 2}$ No significant $(p>0.05)$ difference between values obtained on casein and on soy protein diets. ${ }^{* 3}$ LDL-cholesterol concentrations were determined from 1) the $d>1.006$ minus the $d>1.063 \mathrm{~g} / \mathrm{ml}$ fractions, 2) the $d>1.006$ minus the $d>1.006 \mathrm{~g} / \mathrm{ml}$ fraction after LDL precipitation, 3) $d<1.063$ minus the $d<1.006 \mathrm{~g} / \mathrm{ml}$ fraction, and 4) the plasma concentrations of total cholesterol, triglyceride, and the HDL-C according to Ref. (16). ${ }^{* 4}$ HDL-cholesterol concentrations were determined from 1) the $d>1.063 \mathrm{~g} / \mathrm{ml}$ fraction, 2) plasma after precipitation with heparin- $\mathrm{MnCl}_{2}$, and 3) the $d>1.006 \mathrm{~g} / \mathrm{ml}$ fraction after precipitation of $\mathrm{LDL}$. ${ }^{* 5} \mathrm{HDL}_{2}$-cholesterol concentrations were determined from the $d>1.063$ minus the $d>1.125 \mathrm{~g} / \mathrm{ml}$ fraction. ${ }^{* 6} \mathrm{HDL}_{3}$-cholesterol concentrations were determined from the $d>1.125 \mathrm{~g} / \mathrm{ml}$ fraction.

Table 5. Plasma lipoprotein-cholesterol concentrations in female and male subjects, taking cholesterol-enriched diets, on days 24,28 , and 32 of each dietary period. ${ }^{* 1}$

\begin{tabular}{|c|c|c|c|}
\hline & Casein diet & Soy protein diet & $p$ \\
\hline \multicolumn{4}{|l|}{ Women $(n=6)$} \\
\hline \multicolumn{4}{|l|}{ Cholesterol intake } \\
\hline $\mathrm{mg} / \mathrm{d}$ & $482 \pm 84^{\mathrm{a}}$ & $419 \pm 73^{b}$ & \\
\hline $\mathrm{mg} / \mathrm{kg} / \mathrm{d}$ & $8.8 \pm 2.1$ & $7.7 \pm 1.7$ & \\
\hline LDL-C, ${ }^{* 3} \mathrm{mg} / 100 \mathrm{ml}$ & $75 \pm 27$ & $65 \pm 10$ & $\mathrm{NS}^{* 2}$ \\
\hline HDL-C,${ }^{* 3} \mathrm{mg} / 100 \mathrm{ml}$ & $53 \pm 9$ & $61 \pm 12$ & NS \\
\hline $\mathrm{HDL}_{2}-\mathrm{C},{ }^{* 3} \mathrm{mg} / 100 \mathrm{ml}$ & $34 \pm 13$ & $41 \pm 15$ & NS \\
\hline \multicolumn{4}{|l|}{$\operatorname{Men}(n=5)$} \\
\hline \multicolumn{4}{|l|}{ Cholesterol intake } \\
\hline $\mathrm{mg} / \mathrm{d}$ & $629 \pm 93^{\mathrm{a}}$ & $567 \pm 93^{b}$ & \\
\hline $\mathrm{mg} / \mathrm{kg} / \mathrm{d}$ & $8.5 \pm 1.0$ & $7.7 \pm 1.1$ & \\
\hline LDL-C, $\mathrm{mg} / 100 \mathrm{ml}$ & $93 \pm 28$ & $75 \pm 16$ & $<0.05$ \\
\hline HDL-C, mg/100 ml & $43 \pm 7$ & $50 \pm 10$ & $<0.02$ \\
\hline $\mathrm{HDL}_{2}-\mathrm{C}, \mathrm{mg} / 100 \mathrm{ml}$ & $29 \pm 8$ & $34 \pm 9$ & $<0.02$ \\
\hline
\end{tabular}

${ }^{* 1}$ Mean \pm SD. ${ }^{* 2}$ No significant $(p>0.05)$ difference between the dietary periods. ${ }^{* 3}$ For procedures used to determine LDL-C (method 1), HDL-C (method 1$)$ and $\mathrm{HDL}_{2}-\mathrm{C}$ see Table 4 , footnotes.

${ }^{\mathrm{a}, \mathrm{b}}$ Cholesterol intake by men significantly greater than that by women $\left(p<0.05,{ }^{\mathrm{a}}, p<0.02^{\mathrm{b}}\right)$. 
Both women and men had lower plasma concentrations of LDL-C and higher levels of HDL-C and $\mathrm{HDL}_{2}-\mathrm{C}$ on cholesterol-enriched diets containing soy protein than casein. But only in the men did the differences between the two proteins achieve statistical significance (Table 5). Although the greater effects observed in men might be due to a significantly greater intake of cholesterol, the intake was the same for the 2 sexes when adjusted for differences in body weight. The data therefore suggest a greater sensitivity of men to the differential effects of the two dietary proteins.

\section{Discussion}

The results of the present study show that dietary casein and soy protein can have similar or quite different effects on plasma lipoprotein levels in normolipidemic subjects, depending on the level of cholesterol intake. With a daily intake of $500 \mathrm{mg}$, which is average for the adult Danish population, soy protein caused both a lowering of LDL-C and an increase in HDL- and $\mathrm{HDL}_{2}-\mathrm{C}$ when substituted for casein. But when the cholesterol intake was less than $100 \mathrm{mg} / \mathrm{d}$, the 2 dietary proteins had indistinguishable effects on lipoprotein concentrations. Since the chemical composition of the major lipoprotein classes remained constant under the various dietary regimens $(13,14)$, the differences observed in lipoprotein-cholesterol concentrations represent equivalent differences in plasma levels of total lipoprotein mass of the various lipoproteins.

Our finding that cholesterol-enriched diets are necessary to bring out the different effects of animal and plant dietary proteins on plasma lipoproteins is in agreement with studies in experimental animals. Thus, in several animal species, such as rat, pig and chicken, cholesterol-rich diets are generally required to reveal a hypocholesterolemic effect of dietary plant proteins (12). The only previous attempt to study interaction of dietary protein and cholesterol in humans involved hypercholesterolemic patients on low cholesterol, soy protein diets. Addition of cholesterol $(500 \mathrm{mg} / \mathrm{d})$ to the soy diet did not affect its marked LDL-lowering effect (6).

The mechanism behind the interaction of dietary proteins and cholesterol is unknown. An increased intestinal uptake of cholesterol and bile acids on casein diets, as compared to soy protein diets, has been proposed to be the primary cause of the hypercholesterolemic effect of casein in experi- mental animals (20). In this view, effects of dietary proteins on hepatic synthetic rates of cholesterol and bile acids and on lipoprotein receptor activity are secondary to the effects on intestinal steroid absorption. Our finding, that an increased cholesterol intake, as opposed to a low intake, brings out different effects of the 2 dietary proteins on lipoprotein levels, would appear to agree with this hypothesis. However, measurements of neutral and acid fecal steroid excretion by hypercholesterolemic, hypertriglyceridemic and normolipidemic individuals showed no significant differences between soy protein and casein or mixed protein diets on these parameters $(2,21)$. It should be added, however, that the daily cholesterol intake in these 2 studies was $200 \mathrm{mg}$ or less, and thus the lack of effects on fecal steroid excretion may not be relevant to the findings of the present study.

If dietary casein causes an increased intestinal uptake of cholesterol and bile acids, compared to soy protein, this would be expected to reduce both hepatic LDL-receptor activity and fractional catabolic rates of LDL and consequently increase plasma LDL-C levels. A recently published study in rabbits showed indeed that casein both increased LDL-C concentrations and decreased fractional catabolic rates of LDL, compared to soy protein(22). Preliminary observations in human studies, employing the cholesterol-enriched diets described in the present report, showed however identical fractional catabolic rates on casein and soy protein diets, of both native and modified LDL (23). These findings thus suggest that the differences in LDL-concentrations in man may be due to diet-induced differences in LDL-production rates rather than catabolic rates. Since LDL is derived mainly from small VLDL (Sf 20-60) and IDL, soy protein and casein may in man affect production of these precursors or their transformation into LDL. Another possibility is that de novo hepatic LDL production is affected.

The increased plasma levels of HDL on cholesterol-enriched soy protein diet, compared to casein, may due either to an increased synthesis or a decreased rate of elimination. Observations in rabbits suggest that dietary soy protein, compared to casein, accelerates VLDL turnover(24), which might bring about an increased HDL production. This possibility is in agreement with a human turnover study of apo B in large VLDL (Sf 60-400) in hypercholesterolemic patients(25) showing a 
significant increase in fractional catabolic rate of VLDL-apo B on soy protein compared to a mixed protein diet. This effect on VLDL turnover thus might explain how an increased HDL production could come about, although it does not explain why the level of cholesterol intake should influence HDL production.

We thank Ninn Buch Petersen, Hance Merete Olsen, Grethe Sejersen and Anne Trolle-Christensen for expert technical assistance; Kirsten Andersen for help in designing and making the diets; and the participants for their dedication.

This work was supported by the Danish Heart Foundation.

\section{REFERENCES}

1) Goldberg, A. P., Lim, A., Kolar, J. B., Grudhauser, J. J., Steinke, F. H., and Schonfeld, G. (1982): Soybean protein independantly lowers plasma cholesterol levels in primary hypercholesterolemia. Atherosclerosis, 43, 355-368.

2) Grundy, S. M., and Abrams, J. J. (1983): Comparison of actions of soy protein and casein on metabolism of plasma lipoproteins and cholesterol in humans. Am. J. Clin. Nutr., 38, 245-252.

3) Sacks, F. M., Breslow, J. L., Wood, P. G., and Kass, E. H. (1983): Lack of an effect of dairy protein (casein) and soy protein on plasma cholesterol of strict vegetarians. An experiment and a critical review. $J$. Lipid Res., 24, 1012-1020.

4) Wolfe, B. M., and Giovanetti, P. M. (1985): Elevation of VLDL-cholesterol during substitution of soy protein for animal protein in diets of hypercholesterolemic Canadians. Nutr. Rep. Int., 32, 1057-1065.

5) Carroll, K. K., Giovanetti, P. M., Huff, M. W., Moase, O., Roberts, D. C. K., and Wolfe, B. M. (1978): Hypocholesterolemic effect of substituting soybean protein for animal protein in the diet of healthy young women. Am. J. Clin. Nutr., 31, 1312-1321.

6) Sirtori, C. R., Gatti, E., Mantero, O., Conti, F., Agradi, E., Tremoli, E., Sirtori, M., Fraterrigo, L., Tavazzi, L., and Kritchevsky, D. (1979): Clinical experience with the soybean protein diet in the treatment of hypercholesterolemia. Am. J. Clin. Nutr., 32, 1645-1658.

7) Raaij, J. M. A. Van, Katan, M. B., Hautvast, J. G. A. J., and Hermus, R. J. J. (1981): Effects of casein versus soy protein diets on serum cholesterol and lipoproteins in young healthy volunteers. Am. J. Clin. Nutr., 34, 1261-1271.
8) Raaij, J. M. A. Van, Katan, M. B., West, C. E., and Hautvast, J. G. A. J. (1982): Influence of diets containing casein, soy isolate and soy concentrate on serum cholesterol and lipoproteins in middle-aged volunteers. Am. J. Clin. Nutr., 35, 925-934.

9) Kritchevsky, D., Tepper, S. A., Williams, D. E., and Story, J. A. (1977): Experimental atherosclerosis in rabbits fed cholesterol-free diets. 7. Interaction of animal and vegetable protein with fiber. Atherosclerosis, 26, 397-403.

10) Kritchevsky, D. (1979): Vegetable protein and atherosclerosis. J. Am. Oil Chem. Soc., 56, 135-140.

11) Kritchevsky, D., Tepper, S. A., Davidson, L. M., Fisher, E. A., and Klurfeld, D. M. (1989): Experimental atherosclerosis in rabbits fed cholesterol-free diets. 13. Interaction of proteins and fat. Atherosclerosis, 75, 123-127.

12) Terpstra, A. H. M., Hermus, R. J. J., and West, C. E. (1983): The role of dietary protein in cholesterol metabolism. World Rev. Nutr. Diet., 42, 1-55.

13) Meinertz, H., Faergeman, O., Nilausen, K., Chapman, M. J., Goldstein, S., and Laplaud, P. M. (1988): Effects of soy protein and casein in low cholesterol diets on plasma lipoproteins in normolipidemic subjects. Atherosclerosis, 72, 63-70.

14) Meinertz, H., Nilausen, K., and Faergeman, O. (1989): Soy protein and casein in cholesterol-enriched diets: effects on plasma lipoproteins in normolipidemic subjects. Am. J. Clin. Nutr., 50, 786-793.

15) Warnick, G. R., and Albers, J. J. (1978): A comprehensive evaluation of the heparin-manganese precipitation procedure for estimating high density lipoprotein cholesterol. J. Lipid Res., 19, 65-76.

16) Friedewald, W. T., Levy, R. I., and Fredrickson, D. S. (1972): Estimation of the concentration of low-density lipoprotein cholesterol in plasma, without use of the preparative ultracentrifuge. Clin. Chem., 18, 499-502.

17) Abell, L. L., Levy, B. B., Brodie, B. B., and Kendall, F. E. (1952): A simplified method for the estimation of total cholesterol in serum and demonstration of its specificity. J. Biol. Chem., 195, 357-366.

18) Soloni, F. G. (1971): Simplified manual micro method for determination of serum triglycerides. Clin. Chem., 234, 466-468.

19) Keys, A. (1984): Serum cholesterol response to dietary cholesterol. Am. J. Clin. Nutr., 40, 351-359.

20) Beynen, A. C., Van der Meer, R., and West, C. E. (1986): Mechanism of casein-induced hypercholesterolemia: Primary and secondary features. Atherosclerosis, 60, 291-293.

21) Fumagalli, R., Soleri, L., Farina, R., Musanti, R., Mantero, O., Noseda, G., Gatti, E., and Sirtori, C. R. (1982): Fecal cholesterol excretion studies in type 
II hypercholesterolemic patients treated with the soybean protein diet. Atherosclerosis, 43, 341-353.

22) Samman, S., Kosla, P., and Carroll, K. K. (1989): Effects of dietary casein and soy protein on metabolism of radiolabelled low density apolipoprotein B in rabbits. Lipids, 24, 169-172.

23) Meinertz, H., Nilausen, K., Packard, C. J., and Shepherd, J.: Unpublished observations.

24) Roberts, D. C. K., Stalmach, M. E., Khalil, M. W., Hutchinson, J. C., and Carroll, K. K. (1981): Effects of dietary protein on composition and turnover of apoproteins in plasma lipoproteins of rabbits. Can. J. Biochem., 59, 642-648.

25) Huff, M. W., Giovanetti, P. M., and Wolfe, B. M. (1984): Turnover of very low-density lipoproteinapoprotein B is increased by substitution of soybean protein for meat and dairy protein in the diets of hypercholesterolemic men. Am. J. Clin. Nutr., 39, 888-897. 